\title{
Influence of temperature and food availability on juvenile European anchovy Engraulis encrasicolus at its northern boundary
}

\author{
Kristina Raab ${ }^{1,2, *}$, Marcos Llope ${ }^{3}$, Leo A. J. Nagelkerke ${ }^{1}$, Adriaan D. Rijnsdorp ${ }^{1,2}$, \\ Lorna R. Teal ${ }^{2}$, Priscilla Licandro ${ }^{4}$, Piet Ruardij ${ }^{5}$, Mark Dickey-Collas ${ }^{6}$ \\ ${ }^{1}$ Wageningen University Aquaculture and Fisheries Department, PO Box 338, 6700 AH Wageningen, The Netherlands \\ ${ }^{2}$ Institute for Marine Resources and Ecosystem Studies (IMARES), PO Box 68, 1970 AB Ijmuiden, The Netherlands \\ ${ }^{3}$ Instituto Español de Oceanografia (IEO), Muelle de Levante (Puerto Pesquero), Apdo. 2609, Cádiz 11006, Spain \\ ${ }^{4}$ Sir Alister Hardy Foundation for Ocean Sciences (SAHFOS), The Laboratory, Citadel Hill, Plymouth PL1 2PB, UK \\ ${ }^{5}$ Royal Netherlands Institute for Sea Research (NIOZ), PO Box 59, 1790 AB Den Burg, Texel, The Netherlands \\ ${ }^{6}$ International Council for the Exploration of the Sea (ICES), H. C. Andersens Boulevard 44-46, Copenhagen V 1553, Denmark
}

\begin{abstract}
The European anchovy Engraulis encrasicolus population of the North Sea has increased and spread in recent decades, probably in response to the relaxation of limiting factors in its life history. We use models and empirical data to explore the effects of temperature and food availability during the first growing season on the adult anchovy population across the North Sea. First, we compare simulated growth during summer and autumn, from a dynamic energy budget model, with trends in the time series of anchovy survey catch per unit effort. The proportion of the area of the North Sea in which anchovy can grow to $10 \mathrm{~cm}$ (the potential growth habitat) correlates with the abundance of anchovy caught in surveys the following year. Second, spatio-temporal statistical modeling is used to show that anchovy abundance in surveys is related to environmental variables (temperature and food availability). Temperature explains the distribution and abundance of anchovy in the North Sea better than food availability or a combination of both environmental factors. We conclude that variations in growth during the first months of life can impact anchovy life cycle closure. Specifically for the North Sea anchovy, changes in temperature are more important than changes in food availability in allowing the fish to grow to overwintering size, under probably non-food-limited conditions.
\end{abstract}

KEY WORDS: Small pelagic fish growth $\cdot$ Life cycle closure $\cdot$ Range expansions $\cdot$ Generalised additive models $\cdot$ Physiological models

\section{INTRODUCTION}

Species' ranges are being increasingly studied to understand animal and plant responses to anthropogenic impacts, such as climate change (Thomas \& Lennon 1999, Parmesan \& Yohe 2003, Perry et al. 2005). When a species expands its range, some limiting factors that affect the growth or survival of one or more of the distinct life history stages change (e.g. Rijnsdorp et al. 2009) which may increase the con- nectivity between the habitats of the successive life history stages, allowing life cycle closure (sensu Sinclair 1988). When the abundance of southern fish species recently increased in the North Sea, climate change was investigated as a cause (Beare et al. 2004b). However, given that the abundance and spawning of some of these species, like anchovy and sardine, was already high several decades ago (Aurich 1950, 1953), the relevant question is what aspect of the life history has changed to allow for this 
increase at more northern latitudes, regardless of whether anthropogenic climate change is implicated in the mechanism or not.

Here, we explore the apparent range expansion of anchovy Engraulis encrasicolus, a species with southern geographic affinity (Engelhard et al. 2011), in the North Sea since the mid-1990s (Armstrong et al. 1999, Beare et al. 2004a) and consider its population dynamics in light of variability in potential limiting factors and their impact on life cycle closure (Petitgas et al. 2013).

Due to the relative novelty of anchovy in the North Sea, little is known about its life history in this northern part of its range. In a recent synthesis (Petitgas et al. 2012), hypotheses are explored based on the biology of the species in its Bay of Biscay habitat, with the conclusion that the productivity of the first growing season is probably an important control of survival during the first winter in the North Sea. Early life growth may affect fish survival (e.g. Meekan \& Fortier 1996), and both temperature and food are related to early life growth in Japanese anchovy (e.g. Takasuka \& Aoki 2006).

The present study aims to explore which factors during the early life stages (larval to juvenile, termed 'juvenile' from here on) determine the abundance and distribution of anchovy by using 2 modeling approaches (one bio-energetic and one statistical). First, temperature- and food availability-dependent growth of anchovy during its first 6 mo of life was modeled using the dynamic energy budget (DEB) framework (Kooijman 2010) linked to a 3-dimensional ecosystem model. This allowed for the development of an index of habitat suitability for juvenile growth in the North Sea. We expect that years in which simulated habitat suitability is high would correspond to years that have high empirical survey catches in the following winter.

Second, using independent environmental data, statistical modeling (generalised additive modeling [GAM]; Hastie \& Tibshirani 1990, Wood 2006) was carried out to determine whether temperature or food variables or both encountered as juveniles covaried with the distribution and abundance of survey catches of anchovy in the North Sea and which variables provide the most parsimonious explanation of the data.

Using this 2 method approach, we carry out a robust exploration of the overarching hypothesis of the present work - that the limitations to juvenile growth in the summer were relaxed in years that preceded greater catches of adult anchovy in the North Sea.

\section{MATERIALS AND METHODS}

\section{DEB modeling}

The DEB theory (Kooijman 2010) provides a framework that allows an organism's rate of energy assimilation and utilization for body maintenance, growth and reproduction to be modeled as a function of the state of the organism itself (i.e. its age, size and amount of energy reserves) and the state of its environment (i.e. temperature and food availability). The DEB model assumes that assimilation and maintenance are a function of surface area and body volume respectively. Assimilated energy enters the reserves, from which it is allocated to maintenance plus growth (together these are a fraction, kappa, of the reserve pool) and reproduction (1 - kappa). The reader is referred to the original theoretical literature (Kooijman 2010) for a full description of dynamic energy budgets or to van der Meer (2006) for a summary of the approach.

In a recent application of the DEB framework, spatially explicit environmental food and temperature were used as input for simulations of climate change impacts on habitat suitability as reflected in fish growth (Teal et al. 2012). The model simulates changes in the growth of a hypothetical fish and outputs body size-, food- and temperature-dependent growth rates for each North Sea grid cell (daily, $10 \times$ $10 \mathrm{~km}$ ) of the coupled ecosystem model General Estuarine Transport Model - European Regional Seas Ecosystem Model (GETM-ERSEM, www.nioz.nl/ northsea_model, referred to as 'ERSEM' from here on).

Here, we use this model formulation to simulate the daily growth of juvenile North Sea anchovy for each year between 1985 and 2007. That is, for each grid cell, the starting length of the hypothetical fish is converted to volume by cubing the product of length and the species-specific shape coefficient $\left(\delta_{m}\right)$. Then, the volume change is calculated with DEB given environmental temperature and food values from ERSEM, the new volume after $1 \mathrm{~d}$ of growth is converted back to length, and the difference in lengths between days is termed the daily growth potential of the fish.

The DEB parameters used are anchovy-specific and based on empirical data from the Bay of Biscay or experiments, for lack of equivalent North Sea information (Table 1).

The timing of the growing season of anchovy has to be inferred from the sparse available empirical data. The estimated start of spawning time of anchovy in the German Bight is June/July (Alheit et al. 2007), and larvae are present in highest abundances in 
Table 1. Parameter values used in the dynamic energy budget model for anchovy growth

\begin{tabular}{|lcccc|}
\hline Symbol & Dimension & Value & Explanation & Source \\
\hline$\left\{\dot{\mathrm{p}}_{\mathrm{Am}}\right\}$ & $\mathrm{J} \mathrm{cm}^{-3} \mathrm{~d}^{-1}$ & 329 & Maximum surface area specific assimilation rate & Freitas et al. (2010) \\
{$\left[\mathrm{p}_{\mathrm{M}}\right]$} & $\mathrm{J} \mathrm{cm}^{-3} \mathrm{~d}^{-1}$ & 62 & Volume-specific maintenance costs & Freitas et al. (2010) \\
{$\left[\mathrm{E}_{\mathrm{M}}\right]$} & $\mathrm{J} \mathrm{cm}^{-3}$ & 645 & Maximum storage density & Freitas et al. (2010) \\
{$\left[\mathrm{E}_{\mathrm{G}}\right]$} & $\mathrm{J} \mathrm{cm}^{-3}$ & 5600 & Volume-specific costs of structure & Freitas et al. (2010) \\
$\mathrm{K}$ & - & 0.65 & Fraction of utilised energy spent on maintenance plus growth & Pecquerie et al. (2009) \\
$\mathrm{m}$ & - & 0.172 & Shape coefficient & Pecquerie et al. (2009) \\
$\mathrm{T}_{\mathrm{A}}$ & $\mathrm{K}$ & 9800 & Arrhenius temperature & Pecquerie et al. (2009) \\
$\mathrm{T}_{\mathrm{L}}$ & $\mathrm{K}$ & 278 & Lower boundary of tolerance range & Freitas et al. (2010) \\
$\mathrm{T}_{\mathrm{H}}$ & $\mathrm{K}$ & 305 & Upper boundary of tolerance range & Freitas et al. (2010) \\
$\mathrm{T}_{\mathrm{AL}}$ & $\mathrm{K}$ & 50000 & Rate of decrease at lower boundary & Teal et al. (2012) \\
$\mathrm{T}_{\mathrm{AH}}$ & $\mathrm{K}$ & 100000 & Rate of decrease at upper boundary & Teal et al. (2012) \\
$X_{h}$ & $\mathrm{~J} \mathrm{~cm}$ & 0.000069 & Saturation coefficient & Teal et al. (2012) \\
$\mathrm{T}_{\mathrm{ref}}$ & $\mathrm{K}$ & 293 & Reference temperature used & Freitas et al. (2010) \\
\hline
\end{tabular}

June to July in the Helgoland Roads in the German Bight (Alheit et al. 2012), but it is possible that spawning may continue until July/August (speculated by Kanstinger \& Peck 2009). Therefore, the yearly growth simulation was carried out from 1 June (day 152 of the year) to the end of the year, and in each grid cell of the North Sea, a starting length of $0.5 \mathrm{~cm}$ was used to match the anchovy age at first feeding (off Portugal; Ré 1996).

Daily fish length reached by a certain date was calculated by summing all positive growth potentials across previous days in the model, as we work with the assumption that the fish cannot shrink. We use this fish length to display model results as length is a more tangible measure for comparison with empirical data and also more commonly used in fisheries biology than the more abstract growth potential. We also compute the proportion of the North Sea containing suitable habitat for juvenile anchovy growth. Fish habitat can be defined in many ways, but here, we define suitable habitat as those areas where anchovy can reach a specific threshold size that allows for overwinter survival, as suggested by Petitgas et al. (2012). For Bay of Biscay anchovies, having a body size of 6 to $7 \mathrm{~cm}$ is estimated to result in better overwinter survival, and we assume that in the North Sea this overwintering size would need to be larger due to colder winters. We therefore chose $10 \mathrm{~cm}$ as threshold size.

Two years from the series of analysed years (1985 to 2007) were selected to provide more detailed spatial information, i.e. to show which areas of the North Sea are the most suitable for juvenile anchovy growth: 1988 and 2003. These years had the lowest and highest mean temperatures in Quarter 3 (July to September) respectively at the Marsdiep tidal chan- nel (Wadden Sea), and this location is representative of the southern North Sea (Teal et al. 2008) where we expect young anchovies to be located.

The environmental input data used in the growth model are the output of ERSEM. We use the ERSEM outputs of sea surface temperature (SST) between 0 and $5 \mathrm{~m}$ and potential food availability for pelagic fish, a measure of pelagic zooplankton production, hereafter referred to as secondary production (example output is shown in Fig. 1). ERSEM reports this measure in $\mathrm{mg} \mathrm{C} \mathrm{m} \mathrm{C}^{-2} \mathrm{~d}^{-1}$, and we used the conversion factor of 46 to convert from $\mathrm{mg} \mathrm{C}$ to Joules (Salonen et al. 1976). Food dependency ( $f$ ) in the DEB model is modeled as $f=X /\left(X+X_{h}\right)$. The food density $X$ referred to in $f$ was calculated as the total secondary production available to pelagic fish divided by depth of the water column. The saturation coefficient $X_{h}$ was set to $6.9 \times 10^{-5} \mathrm{~J} \mathrm{~cm}^{-2}$, previously used in the functional response of sole and plaice (Teal et al. 2012). Since not all the secondary pelagic production output by ERSEM is available to anchovy, total levels were calibrated to a lower proportion of the total based on the comparison between available empirical data on anchovy growth and model output for anchovy growth. The mean length of anchovies caught in Weeks 40 and 41 of 2003 (late September to early October) between 51 and $53^{\circ} \mathrm{N}$ and 3 to $5^{\circ} \mathrm{E}$ was $9.9 \mathrm{~cm}$ (Grift et al. 2004, our Fig. 2a). We simulated fish growth for the same geographical area so that the mean lengths reached in the included cells would be the same by that time of year in 2003 by varying the food proportions accordingly (Fig. 2b). The fraction of pelagic secondary production that gave length outputs similar to the empirical data was $1.25 \times 10^{-6}$; we therefore consider this fraction of secondary production to be available to anchovy. 

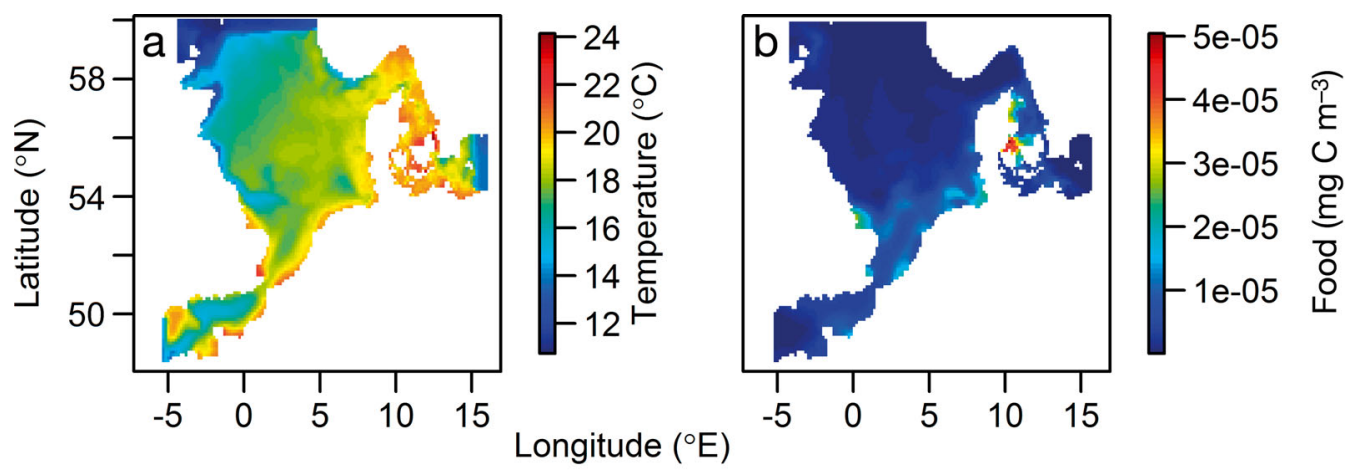

Fig. 1. Example of daily environmental data from the ecosystem model ERSEM used in the simulated growing seasons: (a) temperature and (b) food availability (calibrated to lower fraction $1.25 \times 10^{-6} \mathrm{mg} \mathrm{C} \mathrm{m}^{-3}$ and adjusted to water column depth) for mid-July of 2003

Empirical demersal trawl data from the International Bottom Trawl Survey (IBTS) were extracted from the International Council for the Seas' website to allow for comparison with model output. Anchovy catch per unit effort (CPUE) per length class were summed across length classes for each ICES rectangle $\left(1^{\circ}\right.$ longitude and $0.5^{\circ}$ latitude), and the total abundance in Quarter 1 (January to March) of each year was calculated. Yearly habitat availability (proportion of North Sea cells having reached overwintering size) was then correlated to the next year's Quarter 1 total survey catches using Spearman's rank correlation.

All the analysis and plotting was carried out in $\mathrm{R}$ (R Development Core Team 2012).

\section{Spatio-temporal modeling}

The relationship between anchovy catches in the IBTS (i.e. demersal trawl data) and the potential explanatory variables affecting the catch (temperature and food) is modelled with a non-parametric regression technique, GAM, which uses multiple penalised regression splines (Wood 2006). This framework is very flexible for modeling biological processes, which are not always linear, and in addition it allows for the inclusion of spatial information into the model. Climate can act differentially in both space and time (Stenseth et al. 2002), and the effect of environment on fish populations may vary in space (e.g. Ciannelli et al. 2007, Dingsør et al. 2007). Spatial effects are taken into account by adding a variable representing space as the interaction between latitude and longitude (previous examples include Ciannelli et al. 2007, Llope et al. 2009). In this way, as much available information as possible is included into the model (rather than using averages for North
Sea or across sub-areas of it, for example) since anchovy data are already sparse. The effect of variables for which we do not have information but which still shape the distribution of anchovy are implicit in the spatial variable, and their effect can thus be distinguished from the variables for which we do have data (temperature and food).

We compared 3 model formulations for data from years 1973 to 2006 (pooled), representing the influence of (1) temperature only, (2) food availability only and (3) both combined, during the anchovy growing season on anchovy abundance, using survey catches as a proxy for abundance. All 3 models included additional spatial effects. The response variable is the log-transformed survey CPUE of anchovy ('Catch') at longitude 'Lon' and latitude 'Lat' for Quarter 1 (January to March) of Year $x$. This was related to the colocated position, the SST ('Temp') in Quarter 3 (July to September) of Year $x-1$, and food availability ('Food'), i.e. the total copepods in Quarter 3 of Year $x-1$.

Model 1: Temperature only:

$$
\begin{aligned}
\text { Catch }(\text { Lat,Lon })= & a+s_{1}(\text { Lat,Lon })+ \\
& g_{1}(\text { Temp })+\varepsilon(\text { Lat,Lon })
\end{aligned}
$$

Model 2: Food availability only:

$$
\begin{aligned}
\text { Catch }(\text { Lat }, \text { Lon })= & a+s_{2}(\text { Lat }, \text { Lon })+g_{2}(\text { Food })+ \\
& \varepsilon(\text { Lat }, \text { Lon })
\end{aligned}
$$

Model 3: Both temperature and food:

$$
\begin{aligned}
\text { Catch }(\text { Lat,Lon })= & a+s_{3}(\text { Lat }, \text { Lon })+g_{3}(\text { Temp })+ \\
& g_{4}(\text { Food })+\varepsilon(\text { Lat }, \text { Lon })
\end{aligned}
$$

where $a$ is the intercept, $s_{1}, s_{2}$ and $s_{3}$ are 2-dimensional non-parametric smooth functions describing the effect of location on Catch, and $g_{1}, g_{2}, g_{3}$ and $g_{4}$ are 1-dimensional smooth functions describing the effect of the environment (temperature or food) on Catch. The random error term $\varepsilon$ (Lat,Lon) is assumed to be normally distributed with zero mean and finite variance. 

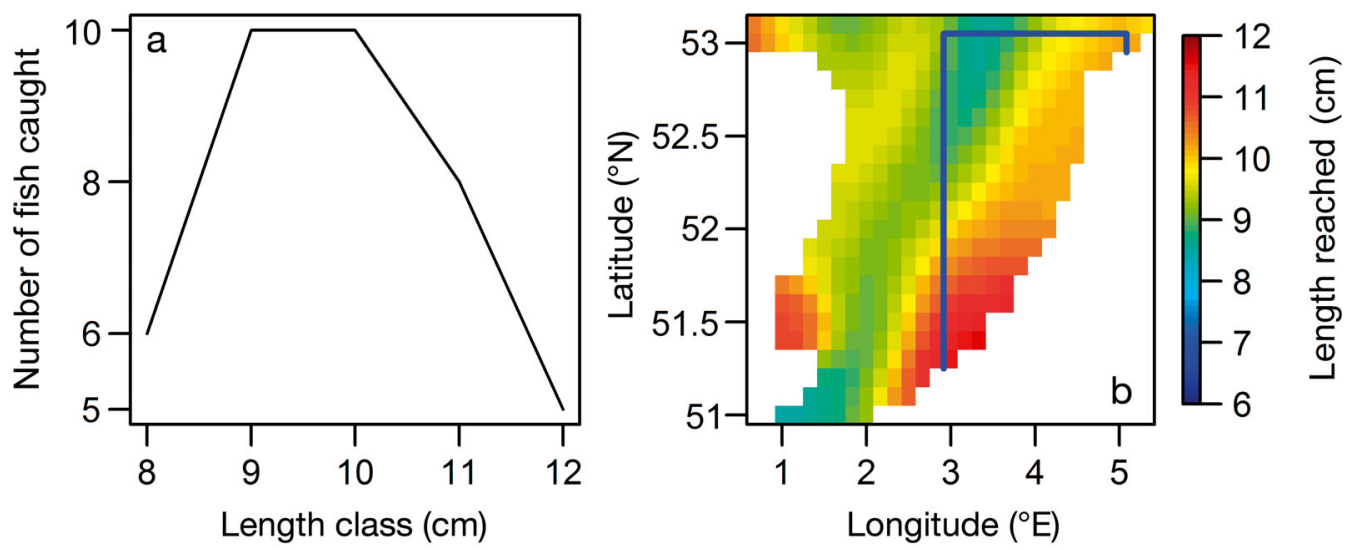

Fig. 2. Calibration of the dynamic energy budget (DEB) model: (a) empirical length frequencies of anchovy in late September to early October and (b) DEB model output by 1 October, both for the Dutch coastal zone (delineated in blue on the map in b) for the year 2003

To avoid over-fitting, we limited the number of smoother knots, $k$, to 4 for the $g$ (environment) functions and to 20 for the $s$ (interaction Lat $\times$ Lon) functions. The analysis was carried out in $\mathrm{R}$ using the 'mgcv' package (Wood 2006) and the data outlined below.

Anchovy CPUE per ICES rectangle (as described above) from Quarter 1 were used. The survey catches dataset suffers from the classical problem of zeroinflation common in fisheries datasets: the full dataset between 1973 and 2006 contains $>90 \%$ zeros. Most likely, some of these zero observations are true zeros (no anchovy presence where sampling occurred), and some are false zeros (anchovy presence but not observed by sampling). While novel statistical approaches are being developed (Liu \& Chan 2010, example in Yu et al. 2012) to discriminate between the 2 potential causes for zeros, we consider that in addressing a range expansion the use of historical data to distinguish true/false zeros is not appropriate. Using a presence-absence approach would be possible, but our interest lies in what factors influence anchovy abundance when it is present, and there are 2 possible approaches to address this issue (detailed by Ciannelli et al. 2008). One is to use the 'conditional model' in which first presenceabsence is modeled and only then is the species abundance modeled, conditional on the species being present. Another approach is to remove the zeros and focus on the presence data only. We choose to exclude the zeros because the conditional model can give contradictory results (Barry \& Welsh 2002), and our interest lies mainly in what accounts for the abundance when anchovy is present rather than what allows for its presence. We try to address a com- bination of what factors in the growing season account for both the presence and abundance in Quarter 1.

SST $\left({ }^{\circ} \mathrm{C}\right)$ data of the International Comprehensive Ocean-Atmosphere Data Set $\left(1^{\circ}\right.$ enhanced) were obtained from the website of the NOAA Earth System Research Laboratory Physical Sciences Division, Boulder, CO (www.cdc.noaa.gov). The resolution of these SST data was $1^{\circ}$ longitude by $1^{\circ}$ latitude, while the ICES rectangle resolution was $1^{\circ}$ longitude and $0.5^{\circ}$ latitude. The SST values were therefore downscaled to the ICES rectangles using loess. The degree of smoothing (value of 'span' in loess) was estimated independently for each year since the spatial structure of the data may vary from year to year. Monthly mean SST were then averaged to give the mean SST for each rectangle for the third quarter of each year as a proxy for the anchovy growing season.

Zooplankton data were obtained from the Sir Alistair Hardy Foundation for Ocean Science's Continuous Plankton Recorder (CPR) dataset. The CPR survey has provided a long-running dataset by using vessels of opportunity to collect samples that are later analysed in the lab (for a detailed description of the dataset, see Warner \& Hays 1994, Richardson et al. 2006).

Recent studies of anchovy diet in the North and Baltic Seas (Schaber et al. 2010, Raab et al. 2011, 2012) indicate that anchovy is a generalist feeder as its diet varies across areas, years and seasons, but copepods make up a big part of the diet. As in previous studies (reviewed by van der Lingen et al. 2009), copepods stand out as an important prey taxon, although the percentage of copepod prey items in the North Sea anchovy diet is lower than in other regions. 
We therefore used the total traverse count of copepods (referred to as total copepods from now on) from the $\mathrm{CPR}$, which includes copepods $\leq 2 \mathrm{~mm}$, to test the effect of prey variability on juvenile anchovy. Moreover, we selected relevant plankton taxa, such as Temora spp. and Centropages spp., which are the most important items for North Sea anchovy by abundance in stomachs (Raab et al. 2011). Total zooplankton biomass (dry weight) was also utilised as a proxy of the overall available zooplankton standing stock. This was derived from CPR records by multiplying the density of 173 copepod and non-copepod taxa by the average dry weight per individual (see Llope et al. 2012 for more details). As the aim was to investigate the potential effect of environmental variability on the growth of the North Sea anchovy population, we related zooplankton records from Quarter 3 (i.e. the anchovy growing season) of a year with anchovy CPUE in Quarter 1 of the following year. Plankton data were first averaged per month and per ICES rectangle, and then the mean value in Quarter 3 was calculated.

Selection of the best version of Model 2 for food only was done by minimizing the generalised crossvalidation (GCV) index, which reflects the trade-off between model complexity and fit to the data (Wood 2006 and explanation by Llope et al. 2012). This model's food measure was subsequently used in Model 3. Then, Models 1, 2 and 3 were compared and selected through minimization of GCV and removal of non-significant variables.

\section{RESULTS}

\section{DEB modeling}

We present results of the DEB model for the whole North Sea as well as for a sub-area, the southern

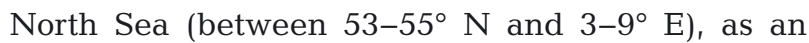
example because spawning is known to take place there and to allow for comparison with other studies (e.g. Alheit et al. 2007, 2012).

The mean lengths reached by anchovy in the North Sea between 1 June and the end of the year during the period 1985 to 2007 are 4.4 to $5.5 \mathrm{~cm}$ (Fig. 3a) and thus show relatively little variation among years $(1.1 \mathrm{~cm})$. Even using this overall North Sea average, however, it is clear that in early years (blue lines in Fig. 3a) in the time series, anchovy reach a lower size than in later years (yellow lines in Fig. 3a). This also applies when considering only the southern North Sea, where average lengths reached range from 7 to $9 \mathrm{~cm}$ (Fig. 3c).
The measure of habitat suitability, expressed as the fraction of area where fish can reach $10 \mathrm{~cm}$, shows more inter-year variation: across the whole North Sea, the proportion varies between 0 in the year 1986 and 0.11 in 2003 (Fig. 3b). Only 1986 had even lower habitat suitability than the example year for cold temperatures (1988). In 1986, in no part of the North Sea did anchovies reach the overwintering size of $10 \mathrm{~cm}$. In the southern North Sea, the proportion of suitable habitat varies between 0 in a suite of years (during the 1980s, 1990s and some from the 2000s) and 0.24 in 2006 (Fig. 3d).

The areas of the North Sea where anchovy would be able to reach sizes of $\geq 10 \mathrm{~cm}$ according to the DEB model are similar in cold and warm years, illustrated (in Fig. 4) by the maps for 1988 (fraction of suitable habitat: 0.02) and 2003 (fraction suitable habitat: 0.11). Growth is highest in the southern North Sea, including the Dogger Bank, and around Denmark. It also appears that most of the positive growth has happened by 1 October and starts leveling off after this period (day 274 of the year, Fig. 3).

Simulation results and empirical abundance from the following year's first quarter, indicative of survival, are well correlated (Fig. 5; Spearman's rank correlation, $\sigma=0.78 ; \mathrm{p}<0.001)$. When years corresponding to zero catches in the IBTS are removed (6 years total), the same significant positive relationship holds (Spearman's rank correlation, $\left.\mathrm{r}_{\mathrm{S}}=0.65 ; \mathrm{p}=0.004\right)$.

\section{Spatio-temporal modeling}

The best model fit for the relationship between anchovy CPUE and food variables (i.e. different versions of Model 2) in the period from 1973 to 2006 was for the model that used log(zooplankton biomass) as it had the lowest GCV, and therefore, $\log ($ zooplankton biomass) was chosen as most appropriate zooplankton variable to represent anchovy food in Model 3.

The best model fit for the relationship between anchovy CPUE and environmental variables in Models 1 to 3 (temperature, food, or both) was for the model that included temperature only: Model 1 $\left(\mathrm{GCV}=2.1835 ; \mathrm{R}^{2}=0.10 ;\right.$ deviance explained $=$ $12.8 \%$; Table 2, Fig. 6) based on minimization of GCV and removal of non-significant variables. Indeed, while Model 3 had a lower GCV than the other models $\left(\mathrm{GCV}=2.1199 ; \mathrm{R}^{2}=0.738\right.$; deviance explained $=10.1 \%$; Table 2), it included a nonsignificant variable (food, $p=0.186$ ) that did not show a significant relationship with anchovy abundance and could thus be removed. 

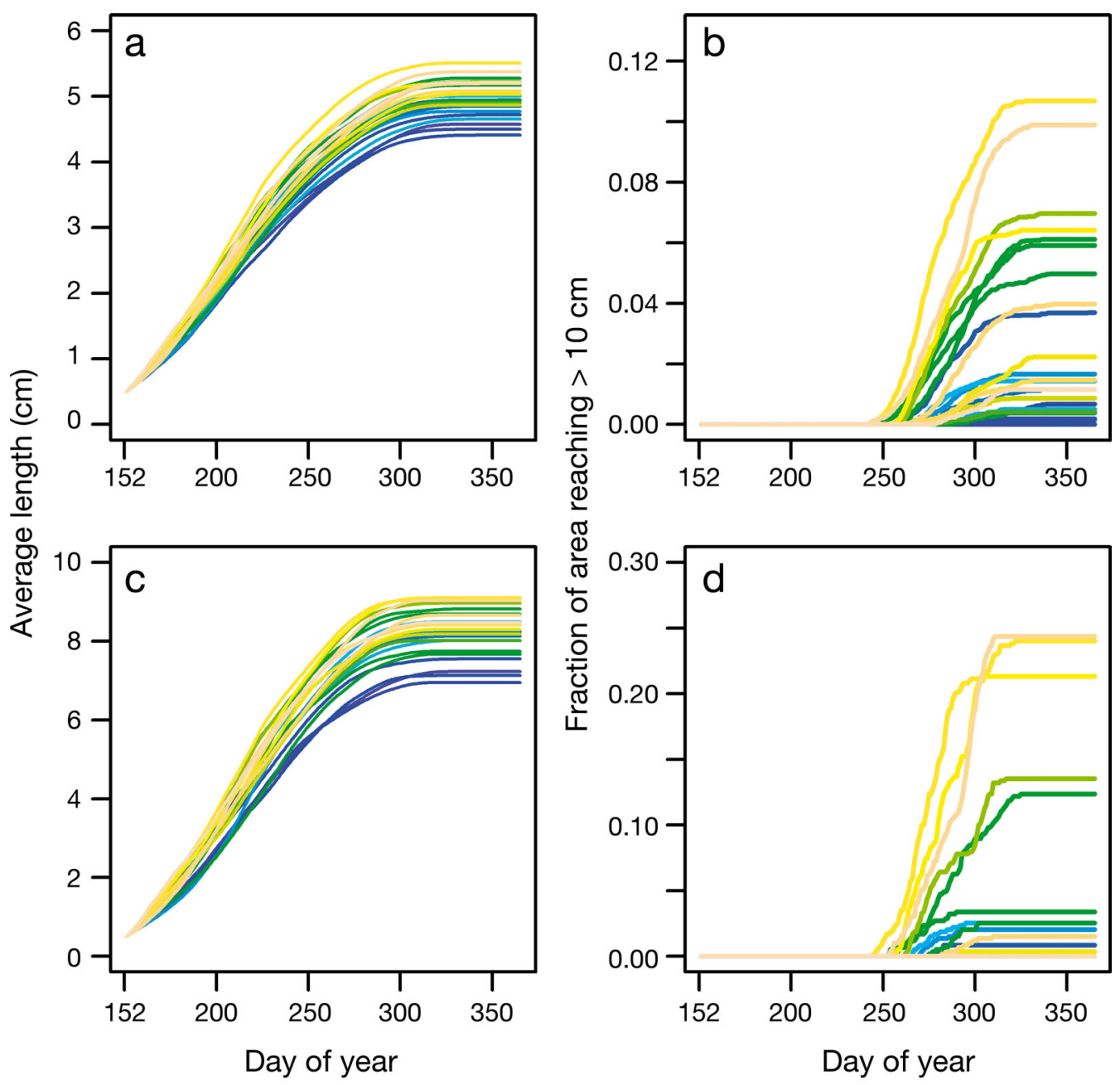

Fig. 3. Dynamic energy budget model results: $(a, c)$ mean length attained and $(b, d)$ proportion of North Sea where lengths above $10 \mathrm{~cm}$ are attained by 31 December by anchovy in $(\mathrm{a}, \mathrm{b})$ the whole North Sea and $(\mathrm{c}, \mathrm{d})$ in the Southern North Sea. Each line represents 1 year, and the colours change gradually from blue to green to yellow as years progress from 1985 to 2007

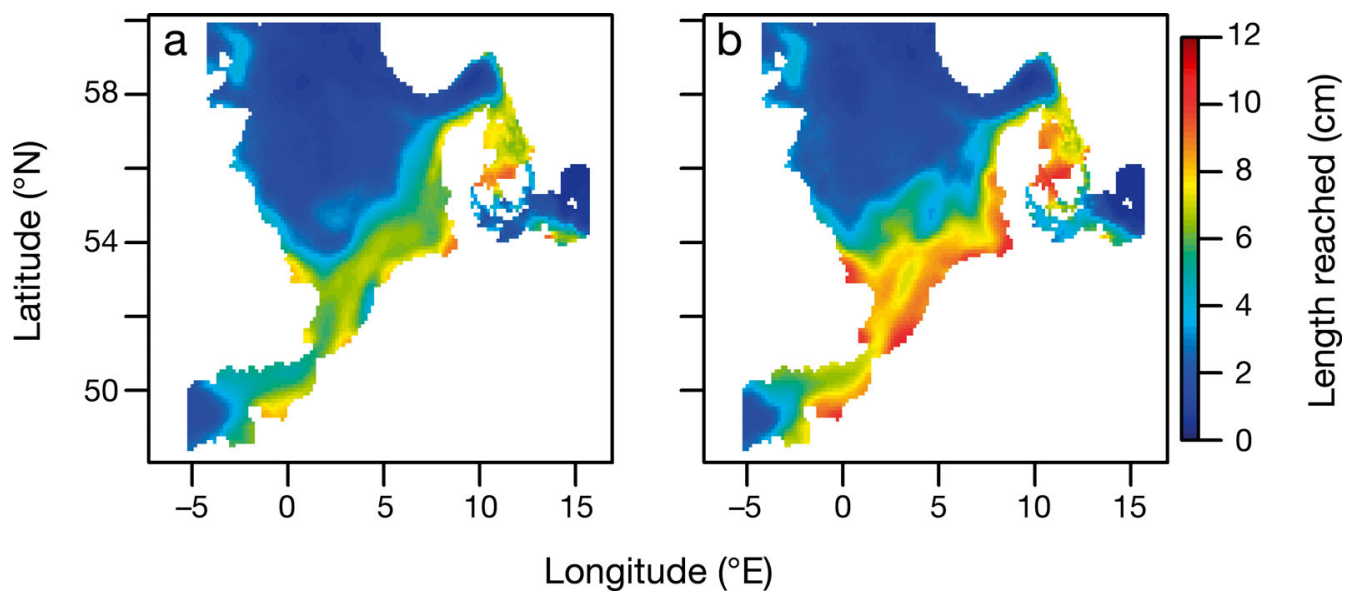

Fig. 4. Examples of (a) a low and (b) a high growth year for anchovy: lengths reached by 1 October in (a) 1988 and (b) 2003 (these years have a fraction of 0.002 and 0.107 of the North Sea, respectively, where anchovy can reach $>10 \mathrm{~cm}$ ) 
Model 2, with only food as an explanatory variable, had the lowest coefficient of determination $\left(\mathrm{R}^{2}\right)$ and accounted for the least of the deviance $\left(R^{2}=0.05\right.$, deviance explained $=7.46 \%$ with a GCV of 2.1546; Table 2). The relationship between food and anchovy CPUE was close to zero in both Models 2 and 3 (Figs. $7 \mathrm{~b} \& 8 \mathrm{~b}$, respectively) and non-significant in both ( $p=0.184$ and $p=0.186$, respectively; Table 2 ).

The spatial effect found in Model 1 with only temperature (see Fig. 6a) indicates more CPUE off the Scottish coast and on the Dogger Bank, as well as around Denmark. Temperature during the previous growing season has a positive effect on anchovy CPUE (Model 1, Fig. 6b) between 12 and $15^{\circ} \mathrm{C}$, a

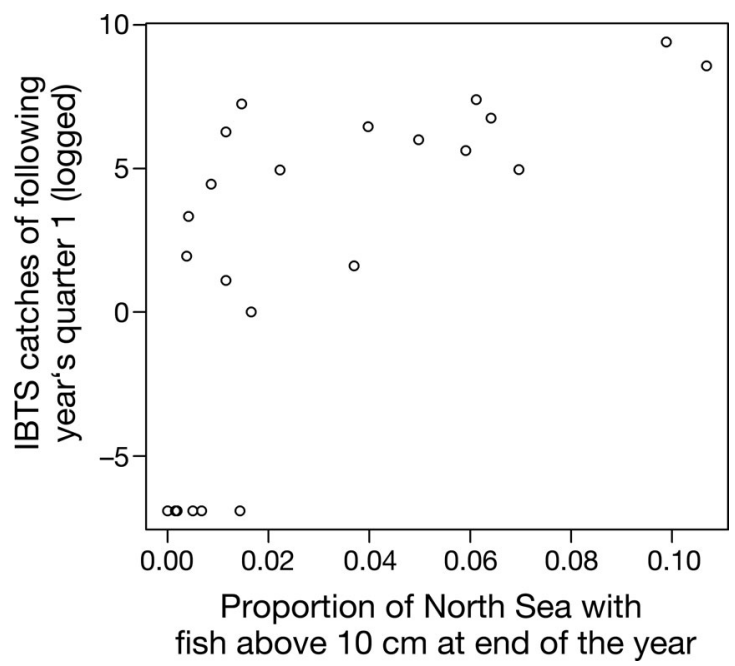

Fig. 5. Relationship between survey catches (from the International Bottom Trawl Survey) and proportion of the North Sea in the previous growing season that was suitable to anchovy (proxy used is the area where anchovy can attain $>10 \mathrm{~cm}$ in length) weak effect on the CPUE between 15 and $17^{\circ} \mathrm{C}$ and a strong positive effect again between 17 and $19^{\circ} \mathrm{C}$.

The residuals did not show any particular pattern, and temporal and spatial autocorrelation were not a problem due to the low proximity in time and space between the different observations after removing the zeros from the dataset.

\section{DISCUSSION}

The benefit of using both the spatio-temporal modeling and DEB approaches is that while the former indicates which environmental factors co-vary in time and space, the DEB model simulates the underlying mechanisms. We find that the proportion of North Sea habitat during the anchovy growing season is positively related to the following year's first quarter's anchovy CPUE and that the temperature of the growing season best explains the spatial variation in anchovy abundance and distribution. This supports the hypothesis of expanded thermal habitats as a mechanism for increased summer growth of individuals and better subsequent overwinter survival leading to the anchovy population expansion (Petitgas et al. 2012).

In both cold and warm years, the areas where anchovy can grow best are located in the same areas in the southern North Sea. These regions include areas where a resident anchovy population is found (the Dutch coast; Boddeke \& Vingerhoed 1996) and where a new anchovy spawning area was reported after the population increase (the German Bight; Alheit et al. 2007). This also corresponds roughly to the bathymetry of the North Sea and to shallower, hence warmer, areas.

Table 2. Generalised additive modelling: intercept, effective degrees of freedom (edf) and significance (p-value) of the spatial and environmental covariables in each of the 3 models. Coefficient of determination $\left(\mathrm{R}^{2}\right)$ and generalised cross validation (GCV) score are given per model

\begin{tabular}{|c|c|c|c|c|c|c|}
\hline & \multicolumn{2}{|c|}{ Model 1: TEMP } & \multicolumn{2}{|c|}{ Model 2: FOOD } & \multicolumn{2}{|c|}{ Model 3: BOTH } \\
\hline & Estimate & $\mathrm{p}$-value & Estimate & $\mathrm{p}$-value & Estimate & $\mathrm{p}$-value \\
\hline Intercept & 1.3737 & $<0.001$ & 1.3193 & $<0.001$ & 1.3193 & $<0.001$ \\
\hline \multirow[t]{2}{*}{$\mathrm{SE}$} & 0.0620 & & 0.0661 & & 0.0653 & \\
\hline & edf & $\mathrm{p}$-value & edf & $\mathrm{p}$-value & edf & $\mathrm{p}$-value \\
\hline (Long, Lat) & 13.972 & $<0.001$ & 9.213 & 0.030 & 11.441 & 0.009 \\
\hline Temp & 2.988 & $<0.001$ & - & - & 1.807 & 0.002 \\
\hline Food & - & - & 1.989 & 0.184 & 1.000 & 0.186 \\
\hline $\mathrm{R}^{2}$ & \multicolumn{2}{|c|}{0.1} & \multicolumn{2}{|c|}{0.0525} & \multicolumn{2}{|c|}{0.738} \\
\hline $\mathrm{GCV}$ & \multicolumn{2}{|c|}{2.1835} & \multicolumn{2}{|c|}{2.1546} & \multicolumn{2}{|c|}{2.1199} \\
\hline Deviance explained & \multicolumn{2}{|c|}{$12.8 \%$} & \multicolumn{2}{|c|}{$7.46 \%$} & \multicolumn{2}{|c|}{$10.1 \%$} \\
\hline $\mathrm{n}$ & \multicolumn{2}{|c|}{550} & \multicolumn{2}{|c|}{481} & \multicolumn{2}{|c|}{481} \\
\hline
\end{tabular}


a) Spatial effect

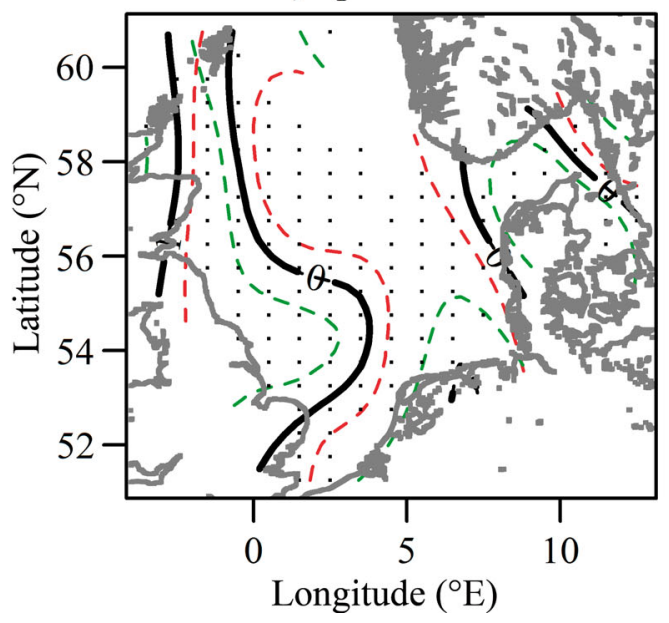

b) Temperature effect

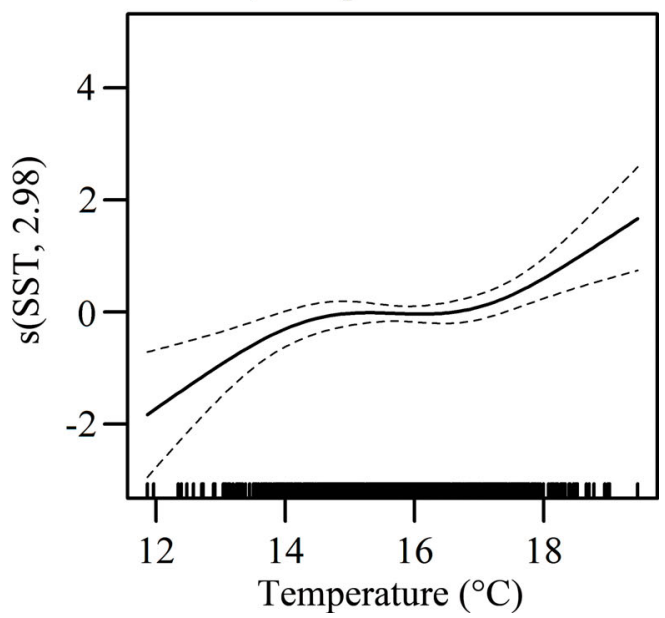

Fig. 6. Effect of space and of temperature on the survey catch per unit effort (CPUE) of anchovy in 1973 to 2006: (a) Spatial contours of anchovy CPUE with upper (red) and lower (green) confidence intervals; (b) partial additive effect of temperature ( $x$-axis) on the CPUE of anchovy ( $y$-axis, number in parentheses indicates the effective degrees of freedom). The dashed lines are the $95 \%$ confidence intervals. The rug plot on the $x$-axis indicates the location of observations

a) Spatial effect

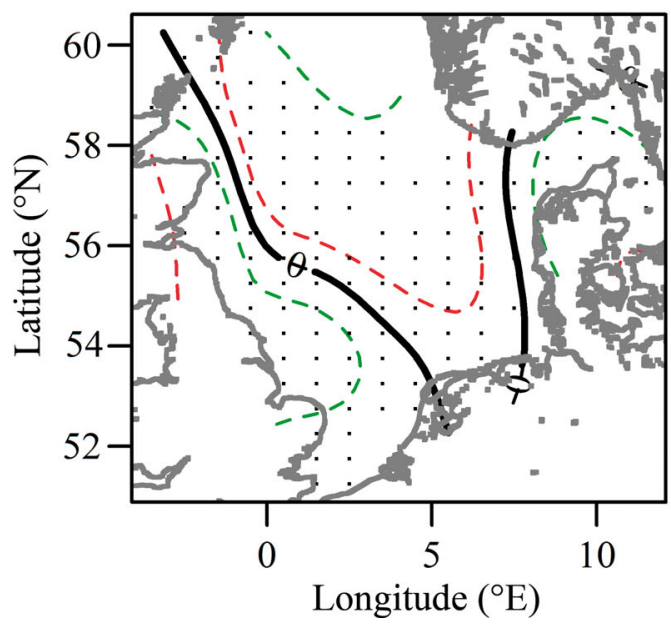

b) Food effect

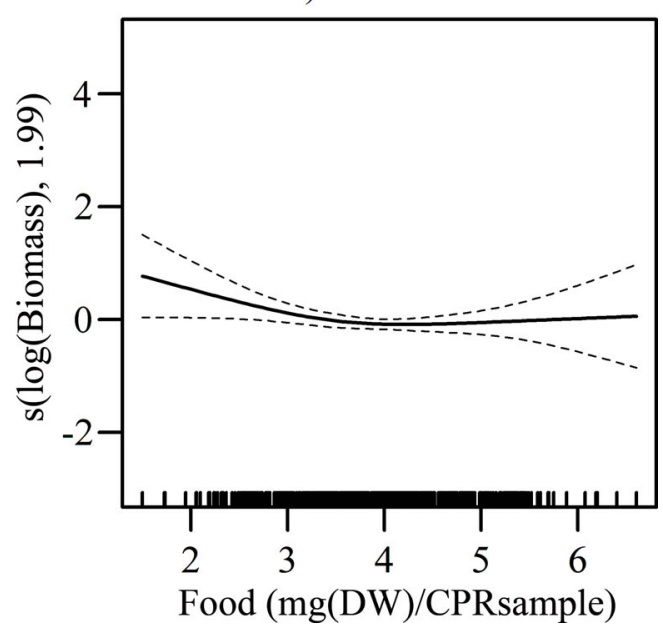

Fig. 7. Effect of space and of food on the survey catch per unit effort (CPUE) of anchovy in years 1973 to 2006: (a) Spatial contours of anchovy CPUE with upper (red) and lower (green) confidence intervals; (b) partial additive effect of food ( $x$-axis) on the CPUE of anchovy ( $y$-axis, number in parentheses indicates the effective degrees of freedom). The dashed lines are the $95 \%$ confidence intervals. The rug plot on the $x$-axis indicates the location of observations. The original food unit is mg dry weight (DW) per continuous plankton recorder (CPR) sample, which has a nominal volume of $3 \mathrm{~m}^{3}$

Generally, the location of high anchovy CPUE found in the GAM does not correspond well to the high growth areas found in the DEB model. In the German Bight for instance, there is a low anomaly in the Quarter 1 CPUE, where DEB simulated growth is highest. CPUE is high on the east coast of the UK, on the Dogger bank and around Denmark. According to the DEB output, the east coast of the UK is a low growth area, the Dogger Bank varies depending on the year, while around Denmark, growth is always high. This discrepancy between high growth areas and high CPUE later is not completely surprising as fish are mobile organisms and often have seasonal migrations. Anchovy is known to partition its nursery and feeding grounds in other systems (e.g. Irigoien et al. 2007), so while it is possible that the fish caught in areas of low growth, e.g. off Scotland, grew there under sub-optimal growth conditions, it seems more likely that they occupied the more suitable habitat areas during the previous summer and then moved 
a) Spatial effect

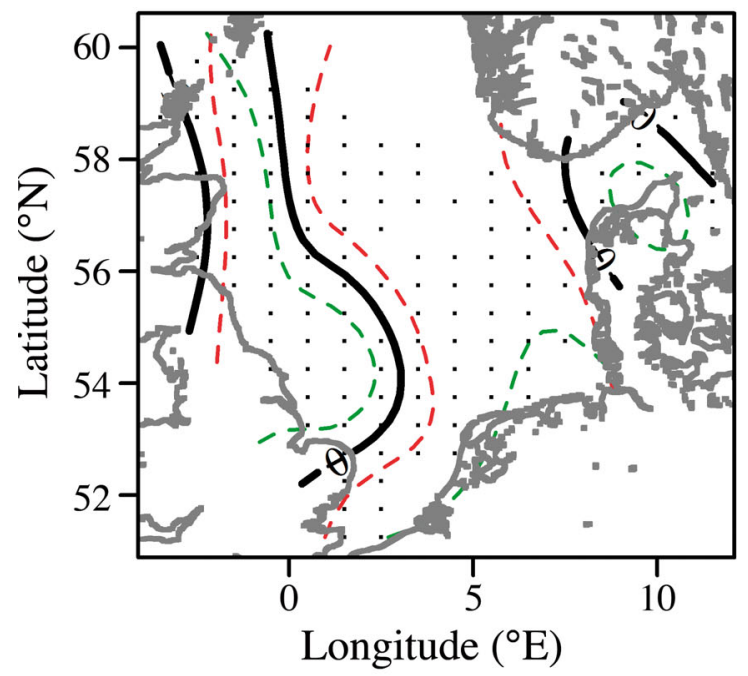

b) Food effect

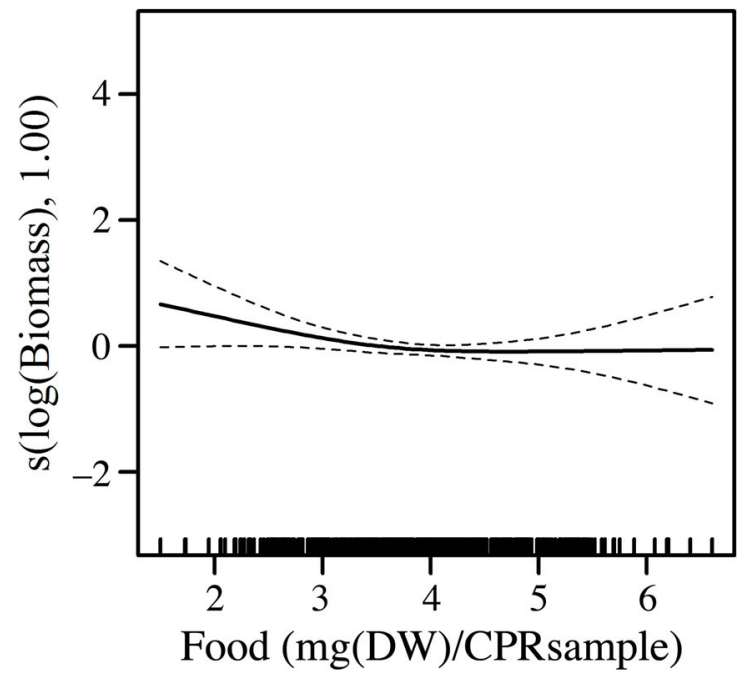

c) Temperature effect

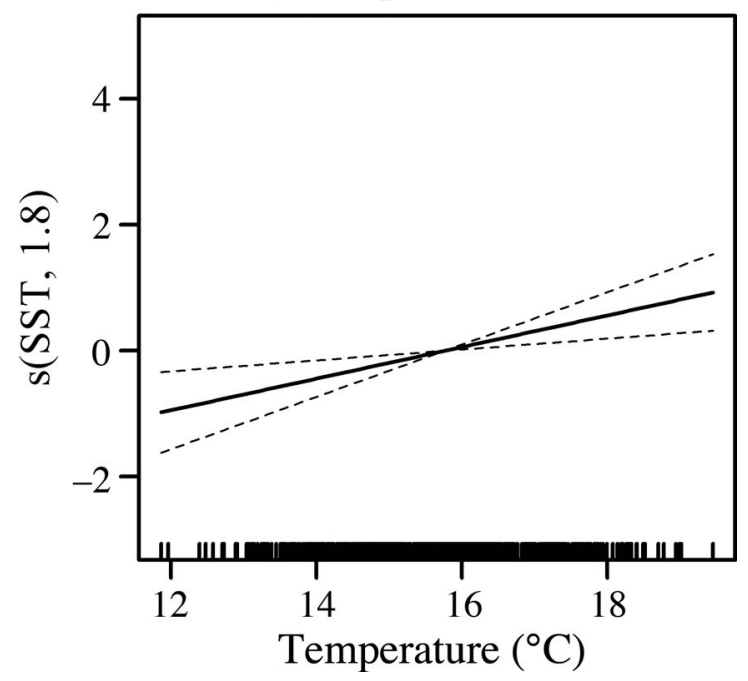

elsewhere, as indicated by earlier studies (Beare et al. 2004a, Alheit et al. 2012). In winter, the SE North Sea cools down, and anchovy may move to warmer waters in the areas supplied by Atlantic inflow of relatively warm water (Southern Bight and along the coast of Scotland and England).

The yearly variability in habitat suitability corresponds to the general increase of anchovy population over time (Beare et al. 2004a), and specifically, the habitat suitability at the end of the year is strongly correlated with the IBTS CPUE of the following year's first quarter. This supports the hypothesis (of Petitgas et al. 2012) that it is the first growing season of North Sea anchovy that determines the abundance in the following year, due to increased winter survival. A different index of habitat suitability developed for older anchovies and based on the rate of reallocation of energy from reproduction buffer to maintenance in the DEB model has shown that the spatial extent of unsuitable areas during winter has decreased for anchovies in the North Sea (Peck et al. 2009). November and December in particular showed large variability throughout the timeseries (1980 to 2004) with a decrease in the percentage of unsuitable area. Thus, it seems likely that in addition to affecting juvenile growth, winter temperatures are also a major influence on adult anchovy via reproduction.

Additional mechanisms related to reproduction and overwintering may have enhanced the population increase of anchovy under warming climatic conditions. First, a warmer growing season implies an acceleration of physiological processes, from assimilation of ingested food to maturation of oocytes and egg batch production, thus increasing the overall frequency of batch production as long as sufficient food is available. Second, under warming conditions, the length of the spawning season increases. According to a field study in the Bay of Biscay, both batch fecundity and batch frequency increase as the spawning season progresses (Motos 1996). Third, temperature since the 1990s has been higher than in the past decades (Hughes et al. 2012), and this may allow for increased overwinter survival of the individuals (see Petitgas et al. 2012).

Fig. 8. Effect of space, food and temperature on the survey catch per unit effort (CPUE) of anchovy in 1973 to 2006: (a) Spatial contours of anchovy CPUE with upper (red) and lower (green) confidence intervals; (b) partial additive effect of food ( $x$-axis) and (c) partial additive effect of temperature ( $x$-axis) on the CPUE of anchovy ( $y$-axis, number in parentheses indicates the effective degrees of freedom). See Fig. 7 for more details 
Our study could be considered limited by the use of sub-optimal gear (a demersal trawl) to derived CPUE indices of survey abundance. One might imagine that small pelagic schooling fish are better sampled with acoustic surveys. However, the IBTS originates from the ICES young herring survey, and the GOV trawl was specifically chosen to sample juvenile clupeids (Heessen et al. 1997). The IBTS is the only comprehensive survey that has charted the population dynamics of North Sea anchovy, similar to the trends expressed by commercial vessels. This IBTS is also the CPUE series used in previous studies (Beare et al. 2004a, Petitgas et al. 2012). In fact, the North Sea acoustic survey (as mentioned by Petitgas et al. 2012) does not catch anchovy. This is thought to occur because the survey is executed in the summer (June/July) in offshore areas (ICES 2012) just when anchovies are spawning in inshore areas (Alheit et al. 2007 , 2012). So the IBTS is the only dataset that regularly records anchovy, and this survey also covers a long period of time and is spatially extensive. Anchovy have been suggested to be benthic in wintertime (Fage 1911), and a loss of reserves in winter and resulting change in buoyancy (Dubreuil \& Petitgas 2009) may support or cause this change, again suggesting that the Quarter 1 IBTS survey is an appropriate and reliable index of anchovy dynamics in the North Sea.

In the spatio-temporal modeling part of the present paper, we use empirical data to disentangle the effects of temperature and food during the growing season. We find that temperature is more important than food in explaining the pattern of abundance and distribution of anchovies. In the German Bight, CPUE is generally lower, possibly because this area is rather shallow and therefore cools down substantially during winter, when anchovy move elsewhere (Alheit et al. 2012, Beare et al. 2004a). Physiologically, one may expect a positive effect of increasing temperature on fish productivity, up to a maximum and followed by a sharp decrease due to e.g. cessation of enzyme activity (Pörtner \& Farrell 2008). The smoothed relationship between temperature and CPUE anomalies that we find here deviates from this expectation. The positive relationship below $15^{\circ} \mathrm{C}$ and above $17^{\circ} \mathrm{C}$ and a stable level in between may indicate that 2 processes are involved. The positive temperature effect up to $15^{\circ} \mathrm{C}$ may reflect the need of anchovy for warm temperatures to spawn (Motos et al. 1996). The increase between 17 and $19^{\circ} \mathrm{C}$ may reflect the expansion of the spawning habitat. Food availability is expected to have a positive effect on fish populations (Brandt 1993) and on young anchovy in Japan (Zenitani et al.
2007), so it seems surprising that no effect is found here. The effect of zooplankton prey on anchovy distribution may have been overridden by that of temperature because since the 1990s the temperature in the southern North Sea has been higher than in previous decades (Hughes et al. 2012). This strengthens the hypothesis that anchovy are unlikely to suffer from food limitation in the North Sea, already suggested previously due to the species being a generalist feeder compared to other likely competitors (Raab et al. 2012). Although the empirical food-availability proxy we used (total zooplankton biomass) may be crude, we consider the results robust as we tried several other measures of food availability from the CPR data based on the present understanding of North Sea anchovy diet and obtained similar results.

Growth is affected by temperature and food availability in anchovy (Basilone et al. 2004, Takasuka \& Aoki 2006), and survival also depends on food (Zenitani et al. 2007). In a comparative study of different anchovy populations in Asia, the respective importance of temperature and food varied by geographic region; however, the synthesis showed that an overall temperature relationship underlies all the relationships, making temperature more important than food availability in those areas (Takasuka \& Aoki 2006). Our results support this finding.

Other factors may affect growth patterns and were not taken into account in our study. Densitydependence can reduce growth in fish (Lorenzen \& Enberg 2002), but this possibility is ignored in our DEB model. Trophic competition can reduce growth, and size-selective predation may affect growth patterns. Different predator species select differently in Japanese anchovy (Takasuka et al. 2003), and cannibalism also occurs (Takasuka et al. 2004). The impacts of same-level and top-down effects on the North Sea anchovy population remain to be studied.

In conclusion, the present multiple-approach study, combining eco-physiological and ecosystem models with analysis of empirical data, provides a supportive and convincing argument about the processes that determined the recent expansion of anchovy in the North Sea. The DEB model is parameter intensive and based on a generic mechanical description of the anchovy's eco-physiology. In this case, we parameterised it using mostly Bay of Biscay anchovy values (Pecquerie et al. 2009, Freitas et al. 2010). However, the North Sea anchovy population is considered to be genetically distinct from the Bay of Biscay population (Zarraonaindia et al. 2012), and parameter values are partly under genetic control (Kooijman 2010); therefore, it is possible that some of the parameter values 
used in the present study may differ from those that are appropriate for North Sea anchovy. The spatiotemporal modeling approach suffers from the same issues as many empirical studies, such as possible biases in measurement or sampling, and moreover, the GAM approach we use is correlative and does not address underlying mechanisms linking the variables of interest. Statistical relationships do not necessarily imply causality, but putting all the information together gives a coherent picture. We think that together the 2 parts of the present paper support the importance of the growing season in the range expansion of anchovy in the North Sea and indicate that habitat suitability in terms of the pre-winter growth is a crucial factor.

Acknowledgements. Thanks to L. Pecquerie, C. Klok and T. van Kooten for helpful discussions about dynamic energy budgets and to D. Beare, L. Ciannelli and V. Bartolino about GAM methods. This research was supported by the EU FP7 grant FACTS (Forage Fish Interactions), grant agreement no. 244966.

\section{LITERATURE CITED}

Alheit J, Voss R, Mohrholz V, Hinrichsen R (2007) Climate drives anchovies and sardines into North Sea. GLOBEC Int Newsl 13:77-78

Alheit J, Pohlmann T, Casini M, Greve W and others (2012) Climate variability drives anchovies and sardines into the North and Baltic Seas. Prog Oceanogr 96:128-139

> Armstrong MJ, Dickey-Collas M, McAliskey M, McCurdy WJ, Burns CA, Peel JAD (1999) The distribution of anchovy Engraulis encrasicolus in the northern Irish Sea from 1991 to 1999. J Mar Biol Assoc UK 79:955-956

Aurich HJ (1950) Besteht fuer 1950 Aussicht auf eine Sardellenfischerei in der Nordsee? Fischereiwelt 2:26-28

Aurich HJ (1953) Verbreitung und Laichverhaeltnisse von Sardelle und Sardine in der suedoestlichen Nordsee und ihre Veraenderungen als Folge der Klimaaenderung. Helgol Wiss Meeresunters 4:175-204

Barry SC, Welsh AH (2002) Generalized additive modelling and zero inflated count data. Ecol Modell 157:179-188

Basilone G, Guisande C, Patti B, Mazzola S, Cuttitta A, Bonanno A, Kallianiotis A (2004) Linking habitat conditions and growth in the European anchovy (Engraulis encrasicolus). Fish Res 68:9-19

Beare D, Burns F, Jones E, Peach K and others (2004a) An increase in the abundance of anchovies and sardines in the north-western North Sea since 1995. Glob Change Biol 10:1209-1213

> Beare DJ, Burns F, Greig A, Jones EG and others (2004b) Long-term increases in prevalence of North Sea fishes having southern biogeographic affinities. Mar Ecol Prog Ser 284:269-278

Boddeke R, Vingerhoed B (1996) The anchovy returns to the Wadden Sea. ICES J Mar Sci 53:1003-1007

Brandt SB (1993) The effect of thermal fronts on fish growth: a bioenergetics evaluation of food and temperature.
Estuaries 16:142-159

Ciannelli L, Dingsør GE, Bogstad B, Ottersen G and others (2007) Spatial anatomy of species survival: effects of predation and climate-driven environmental variability. Ecology 88:635-646

Ciannelli L, Fauchald P, Chan KS, Agostini VN, Dingsør GE (2008) Spatial fisheries ecology: recent progress and future prospects. J Mar Syst 71:223-236

> Dingsør GE, Ciannelli L, Chan KS, Ottersen G, Stenseth NC (2007) Density dependence and density independence during the early life stages of four marine fish stocks. Ecology 88:625-634

> Dubreuil J, Petitgas P (2009) Energy density of anchovy Engraulis encrasicolus in the Bay of Biscay. J Fish Biol 74: 521-534

Engelhard GH, Ellis JR, Payne MR, ter Hofstede R, Pinnegar JK (2011) Ecotypes as a concept for exploring responses to climate change in fish assemblages. ICES J Mar Sci 68: 580-591

Fage L (1911) Recherches sur la biologie de l'anchois. Ann Inst Oceanogr 2:1-41

Freitas V, Cardoso JFMF, Lika K, Peck MA, Campos J, Kooijman SALM, van der Veer HW (2010) Temperature tolerance and energetics: a dynamic energy budget-based comparison of North Atlantic marine species. Philos Trans R Soc Lond B 365:3553-3565

Grift RE, Couperus AS, Ybema MS, Tiën NSH (2004) Base line studies North Sea wind farms: biological data pelagic fish. RIVO report C031/04, Ijmuiden

Hastie TJ, Tibshirani RJ (1990) Generalized additive models. Chapman \& Hall, London

Heessen HJL, Dalskov J, Cook RM (1997) The international bottom trawl survey in the North Sea, the Skagerrak and Kattegat. ICES CM 1997/Y:31

Hughes SL, Holliday NP, Gaillard F, and the ICES Working Group on Ocean Hydrography (2012) Variability in the ICES/NAFO region between 1950 and 2009: observations from the ICES report on ocean climate. ICES J Mar Sci 69:706-719

ICES (2012) Report of the working group of international pelagic surveys (WGIPS), 16-20 January 2012. ICES Headquarters, Copenhagen. ICES CM 2012/SSGESST:21

> Irigoien X, Fiksen Ø, Cotano U, Uriarte A and others (2007) Could Biscay Bay anchovy recruit through a spatial loophole? Prog Oceanogr 74:132-148

> Kanstinger P, Peck M (2009) Co-occurrence of European sardine (Sardina pilchardus), anchovy (Engraulis encrasicolus) and sprat (Sprattus sprattus) larvae in southern North Sea habitats: abundance, distribution and biochemical-based condition. Sci Mar 73:141-152

Kooijman SALM (2010) Dynamic energy budget theory for metabolic organisation. Cambridge University Press, Cambridge

Liu H, Chan KS (2010) Introducing COZIGAM: an R package for unconstrained and constrained zero-inflated generalized additive model analysis. J Stat Softw 35:1-26, www.jstatsoft.org/v35/i11

Llope M, Chan KS, Ciannelli L, Reid PC, Stige LC, Stenseth NC (2009) Effects of environmental conditions on the seasonal distribution of phytoplankton biomass in the North Sea. Limnol Oceanogr 54:512-524

Llope M, Licandro P, Chan KS, Stenseth NC (2012) Spatial variability of the plankton trophic interaction in the North Sea: a new feature after the early 1970s. Glob Change Biol 18:106-117 
Lorenzen K, Enberg K (2002) Density-dependent growth as a key mechanism in the regulation of fish populations: evidence from among-population comparisons. Proc Biol Sci 269:49-54

Meekan MG, Fortier L (1996) Selection for fast growth during the larval life of Atlantic cod Gadus morhua on the Scotian Shelf. Mar Ecol Prog Ser 137:25-37

Motos L (1996) Reproductive biology and fecundity of the Bay of Biscay anchovy population (Engraulis encrasicolus L.). Sci Mar 60:195-207

Motos L, Uriarte A, Valencia V (1996) The spawning environment of the Bay of Biscay anchovy (Engraulis encrasicolus L.). Sci Mar 60:117-140

Parmesan C, Yohe G (2003) A globally coherent fingerprint of climate change impacts across natural systems. Nature 421:37-42

Peck MA, Dickey-Collas M, Heath M, Petitgas P and others (2009) The impact of climate driven physical and biological processes (changes in prey fields) on the vital rates of early life stages of selected, key demersal and pelagic fish species. RECLAIM Deliverable 3.4

> Pecquerie L, Petitgas P, Kooijman SALM (2009) Modeling fish growth and reproduction in the context of the dynamic energy budget theory to predict environmental impact on anchovy spawning duration. J Sea Res 62: 93-105

Perry AL, Low PJ, Ellis JR, Reynolds JD (2005) Climate change and distribution shifts in marine fishes. Science 308:1912-1915

Petitgas P, Alheit J, Peck MA, Raab K and others (2012) Anchovy population expansion in the North Sea. Mar Ecol Prog Ser 444:1-13

Petitgas P, Rijnsdorp AD, Dickey-Collas M, Engelhard GE and others (2013) Impacts of climate change on the complex life cycle of fish. Fish Oceanogr 22:121-139

Pörtner HO, Farrell AP (2008) Physiology and climate change. Science 322:690-692

R Development Core Team (2012) R: a language and environment for statistical computing. R Foundation for Statistical Computing, Vienna, available at www.Rproject.org

Raab K, Nagelkerke LAJ, Boerée C, Rijnsdorp AD, Temming A, Dickey-Collas M (2011) Anchovy Engraulis encrasicolus diet in the North and Baltic Seas. J Sea Res 65: $131-140$

Raab K, Nagelkerke LAJ, Boerée C, Rijnsdorp AD, Temming A, Dickey-Collas M (2012) Dietary overlap between the potential competitors herring, sprat and anchovy in the North Sea. Mar Ecol Prog Ser 470:101-111

Ré P (1996) Anchovy spawning in the Mira estuary (southwestern Portugal). Sci Mar 60:141-153

Richardson AJ, Walne AW, John AWG, Jonas TD and others (2006) Using continuous plankton recorder data. Prog Oceanogr 68:27-74

Rijnsdorp AD, Peck MA, Engelhard GH, Möllmann C, Pinnegar JK (2009) Resolving the effect of climate change on fish populations. ICES J Mar Sci 66:1570-1583

Salonen K, Sarvala J, Hakala I, Viljanen ML (1976) The rela-

Editorial responsibility: Stylianos Somarakis,

Heraklion, Greece tion of energy and organic carbon in aquatic invertebrates. Limnol Oceanogr 21:724-730

Schaber M, Petereit C, Paulsen M (2010) Diet composition and feeding of European anchovy Engraulis encrasicolus in Kiel Bight, western Baltic Sea. J Fish Biol 76: 1856-1862

Sinclair M (1988) Marine populations: an essay on population regulation and specitation. Washington Sea Grant/ University of Washington Press, Seattle

> Stenseth NC, Mysterud A, Ottersen G, Hurrell JW, Chan KS, Lima M (2002) Ecological effects of climate fluctuations. Science 297:1292-1296

Takasuka A, Aoki I (2006) Environmental determinants of growth rates for larval Japanese anchovy Engraulis japonicus in different waters. Fish Oceanogr 15:139-149

Takasuka A, Aoki I, Mitani I (2003) Evidence of growthselective predation on larval Japanese anchovy Engraulis japonicus in Sagami Bay. Mar Ecol Prog Ser 252:223-238

Takasuka A, Oozeki Y, Kimura R, Kubota H, Aoki I (2004) Growth-selective predation hypothesis revisited for larval anchovy in offshore waters: cannibalism by juveniles versus predation by skipjack tunas. Mar Ecol Prog Ser 278:297-302

> Teal LR, de Leeuw JJ, van der Veer HW, Rijnsdorp AD (2008) Effects of climate change on growth of 0-group sole and plaice. Mar Ecol Prog Ser 358:219-230

> Teal LR, van Hal R, van Kooten T, Ruardij P, Rijnsdorp AD (2012) Bio-energetics underpins the spatial response of North Sea plaice (Pleuronectes platessa L.) and sole (Solea solea L.) to climate change. Glob Change Biol 18: 3291-3305

> Thomas CD, Lennon JJ (1999) Birds extend their ranges northwards. Nature 399:213

van der Lingen CD, Bertrand A, Bode A, Brodeur R and others (2009) Trophic dynamics. In: Checkley DM, Alheit J, Oozeki Y, Roy C (eds) Climate change and small pelagic fish. Cambridge University Press, Cambridge

van der Meer J (2006) An introduction to dynamic energy budget (DEB) models with special emphasis on parameter estimation. J Sea Res 56:85-102

Warner AJ, Hays GC (1994) Sampling by the continuous plankton recorder survey. Prog Oceanogr 34:237-256

Wood S (2006) Generalized additive models. Chapman \& Hall/CRC Press, Boca Raton, FL

Yu H, Bi H, Burke B, Lamb J, Peterson W (2012) Spatial variations in the distribution of yearling spring Chinook salmon off Washington and Oregon using COZIGAM analysis. Mar Ecol Prog Ser 465:253-265

Zarraonaindia I, Iriondo M, Albaina A, Pardo MA and others (2012) Multiple SNP markers reveal fine-scale population and deep phylogeographic structure in European anchovy (Engraulis encrasicolus L.). PLoS ONE 7:e42201

Zenitani H, Kono N, Tsukamoto Y (2007) Relationship between daily survival rates of larval Japanese anchovy (Engraulis japonicus) and concentrations of copepod nauplii in the Seto Inland Sea, Japan. Fish Oceanogr 16: $473-478$

Submitted: September 12, 2012; Accepted: May 8, 2013

Proofs received from author(s): July 22, 2013 